Wilfrid Laurier University

Scholars Commons @ Laurier

9-1982

\title{
A Survey of Graduate Education in Community Psychology in Canada
}

Geoffrey Nelson

Wilfrid Laurier University, gnelson@wlu.ca

Bruce M. Tefft

University of Manitoba

Follow this and additional works at: https://scholars.wlu.ca/psyc_faculty

Part of the Psychiatry and Psychology Commons

\section{Recommended Citation}

Nelson, Geoffrey and Tefft, Bruce M., "A Survey of Graduate Education in Community Psychology in Canada" (1982). Psychology Faculty Publications. 21.

https://scholars.wlu.ca/psyc_faculty/21

This Article is brought to you for free and open access by the Psychology at Scholars Commons @ Laurier. It has been accepted for inclusion in Psychology Faculty Publications by an authorized administrator of Scholars Commons@Laurier. For more information, please contact scholarscommons@wlu.ca. 


\title{
A SURVEY OF GRADUATE EDUCATION IN COMMUNITY PSYCHOLOGY IN CANADA
}

\author{
GEOFFREY NELSON \\ Wilfrid Lauries University \\ BRUCE M. TEFFT \\ University of Mamitoha
}

\begin{abstract}
A national survey was conducted to determine current opportunitics for graduate education in community psychology in Canada. The results show expanded offerings for academic and field work education in community psychology in the past decade. Also. faculty perceptions of the goals. activities, and adequacy of training in community psychology were obtained. Finally, similarities and differences between graduate education in community psychology in Canada and the U,S. are noted. Issues related to the development of community psychology in Canada are discussed.
\end{abstract}

A decade ago, the late Park Davidson (1970) reviewed the status of Canadian clinical psychology training programs and concluded that a reorientation of training philosophy was needed. He argued that the dominant scientist-practitioner or "Boulder model" was inadequate and that not enough $\mathrm{Ph}, \mathrm{D}$. personpower was being created for direct clinical service roles such as diagnostician and therapist. Davidson suggested that applied graduate programs in psychology shift towards a researcher-consultant model with an emphasis on program development and evaluation. Lamenting the situation at the time. Davidson concluded that:

Several universities in Canada have expressed vague interest in developing graduate programs in community psychology but no university in Canada has such a program or is concretely developing such a program (1970. p. 111).

At the same time, the results of a survey of Canadian graduate programs in applied psychology (Arthur, 1971) supported Davidson's conclusions. Based on a number of psychologists graduating from applied programs in psychology, Arthur predicted that there would be serious personpower shortages in the future. He estimated that in the next decade there would be, on the average, only one professional psychologist per 20,000 persons in Canada with wide regional variations. Also, there were no graduate programs with a focus on community psychology at the time. In fact, there were only three graduate psychology programs which offered even one course related to community psychology. Thus, while the term "community psychology" was coined in Canada over 20 years earlier (Babarik, 1979), a decade ago there was almost no opportunity for graduate education in this field in Canada.

This research was funded by an initiatory research grant from the Department of Graduate Studies of Wilfrid Laurier University. An earlier version of this paper was presented at the Annual Meeting of the American Psychological Association, Montreal, September 1-5, 1980. Requests for reprints should be sent to Geoffrey Nelson, Department of Psychology, Wilfrid Laurier University, Waterloo, Ontario, Canada, N2L 3C5. 
At the time of Davidson's review, then APA President George Albee (1968, 1970; Albee \& Loeffler, 1971) raised the same issues in the United States about the adequacy of the scientist-practitioner model for clinical training, personpower shortages in the mental health field, and the need for a shift in focus from clinical service to efforts at primary prevention. Surveys of graduate programs in clinical psychology in the U.S. have shown that opportunities for graduate education in community psychology have greatly expanded in the past 20 years. The percentage of U,S. programs offering a distinguishable curriculum in community psychology or community mental health has gradually increased over the years: $2 \%$ in 1962 (Golann, Wurm, \& Magoon, 1964). $15 \%$ in 1967 (Golann, 1970), 20\% in 1970 (Jacob, 1971), and $31 \%$ in 1975 (Meyer \& Gerrard, 1977). There has also been a national training conference in the U.S. (i.e.. the Austin conference reported by Iscoe, Bloom, \& Spielberger, 1977) to support the development of graduate education in community psychology.

The available outdated information then indicates that opportunities for graduate education in community psychology in Canada lag behind those in the U,S. Arthur (1971) found no Canadian programs with a curriculum in community psychology in his 1970 survey, while Jacob (1971) found that $20 \%$ of the U.S. programs he surveyed in 1970 offered such a curriculum. While there is ample information about American community psychology programs, there is no current information regarding the Canadian scene. The major purpose of this survey was to fill that informational gap by determining current opportunities for graduate education in community psychology in Canada. A secondary purpose was to identify the emphases of Canadian programs offering community psychology education and to compare them with the emphases of American community psychology programs reported in previous surveys.

\section{Method}

Several methods were used to identify respondents for the survey. First, through an earlier survey (Tefft, Hamilton, \& Theroux, 1982), 34 university-based psychologists were identified as having an active interest in community psychology education. Secondly, the 1980-1981 graduate catalogues of the 41 Canadian universities offering graduate education in psychology were examined to identify faculty who teach graduate courses in community psychology, Finally, some respondents were identified by other Canadian psychologists through informal conversations and correspondence.

Letters explaining the rationale of the survey were sent along with a bilingual questionnaire (in English and French) to these individuals. The questionnaire consisted of both open-ended and forcedchoice questions covering the following areas: demographic information on the respondent, information pertaining to the respondent's graduate and post-graduate training in community psychology, the respondent's career goals as related to community psychology, information on program offerings (both academic and fieldwork courses) in community psychology, the respondent's views on the essential competencies to be developed in students' graduate education in community psychology, and the respondent's evaluation of how well these goals are attained in his or her program.

One and one-half months after the initial mailing, follow-up questionnaires were sent to those who had not responded. Respondents who did not respond to the follow-up questionnaire were then telephoned to see if they would consent to answering the questionnaire items over the phone.

\section{Results}

A total of 27 faculty who are involved in graduate education in community psychology completed the questionnaire, All but two 
of the respondents are men (92\%) with an average age of 37 years. All of the respondents indicated that their career goals were either moderately or strongly related to community psychology. In their own graduate education, only $40 \%$ of the respondents had more than two graduate courses in community psychology, and only $50 \%$ had a supervised graduate fieldwork course in community psychology. Not surprisingly then, $96 \%$ of the sample indicated that they had had some post-graduate training in community psychology, and $67 \%$ felt that post-graduate experiences, as opposed to graduate experiences, had the most influence on their interests in community psychology.

Regarding the major purpose of the survey, 20 Canadian universities were identi- fied that offer graduate education in community psychology (see Table 1). Slightly more than one-half of the universities $(60 \%)$ have a Ph.D. program, with the remainder offering a terminal M.A. degree. Program offerings vary greatly from one to two community psychology courses taught by one or two faculty to a major area of concentration in community psychology with several faculty teaching an integrated sequence of courses. General survey courses in community psychology and courses in program evaluation are most frequently offered. Most programs (73\%) offer supervised fieldwork in community psychology. but only $10 \%$ (University of Manitoba and Université du Québec à Montréal) offer inter-disciplinary courses pertaining to community psychology.

TABLE 1

Canadian Universities Offering Graduate Education in Community Psychology

\begin{tabular}{|c|c|c|c|c|}
\hline University & $\begin{array}{l}\text { Highest } \\
\text { Degree } \\
\text { Offered }\end{array}$ & $\begin{array}{l}\text { Program } \\
\text { Focus }\end{array}$ & $\begin{array}{l}\text { Academic Courses in } \\
\text { Community Psychology }\end{array}$ & $\begin{array}{l}\text { Fieldwork } \\
\text { Courses in } \\
\text { Community } \\
\text { Psychology }\end{array}$ \\
\hline $\begin{array}{l}\text { Acadia } \\
\text { University }\end{array}$ & M.A. & $\begin{array}{l}\text { Clinical- } \\
\text { Community }\end{array}$ & Community Psychology ${ }^{*}$ & Yes* \\
\hline $\begin{array}{l}\text { British } \\
\text { Columbia } \\
\text { University of }\end{array}$ & Ph.D. & $\begin{array}{l}\text { Clinical- } \\
\text { Community }\end{array}$ & $\begin{array}{l}\text { Community Psychology } \\
\text { Programs* } \\
\text { Special Topics in } \\
\text { Community Psychology } \\
\text { Program Evaluation }{ }^{*}\end{array}$ & Yes: \\
\hline $\begin{array}{l}\text { Dalhousie } \\
\text { University }\end{array}$ & Ph.D. & Research & $\begin{array}{l}\text { Psychological Aspects of } \\
\text { Social Issues* } \\
\text { Community Psychology* }\end{array}$ & Yes* \\
\hline $\begin{array}{l}\text { Guelph, } \\
\text { University of }\end{array}$ & M.A. & $\begin{array}{l}\text { Applied } \\
\text { Social }\end{array}$ & $\begin{array}{l}\text { Community \& Social } \\
\text { Change* } \\
\text { Program Evaluation* } \\
\text { Field Research Techniques* } \\
\text { Applied Social Psychology* } \\
\text { Organizational Behavior } \\
\text { Group Processes }\end{array}$ & Yes* \\
\hline
\end{tabular}




\begin{tabular}{|c|c|c|c|c|}
\hline University & $\begin{array}{l}\text { Highest } \\
\text { Degree } \\
\text { Offered }\end{array}$ & $\begin{array}{l}\text { Program } \\
\text { Focus }\end{array}$ & $\begin{array}{l}\text { Academic Courses in } \\
\text { Community Psychology }\end{array}$ & $\begin{array}{l}\text { Fieldwork } \\
\text { Courses in } \\
\text { Community } \\
\text { Psychology }\end{array}$ \\
\hline $\begin{array}{l}\text { Laval, } \\
\text { Universite de }\end{array}$ & Ph.D. & $\begin{array}{l}\text { Sociale } \\
\text { Commun- } \\
\text { autaire }\end{array}$ & $\begin{array}{l}\text { Psychologie } \\
\text { Communautaire } \\
\text { Sémenaire de Recherche sur } \\
\text { les Reseaux Naturels } \\
\text { Evaluation de Programmes } \\
\text { Intervention de Crise } \\
\text { Problèms Actuels en } \\
\text { Psychologie Sociale }\end{array}$ & Oui \\
\hline $\begin{array}{l}\text { Manitoba, } \\
\text { University of }\end{array}$ & Ph.D. & Clinical & $\begin{array}{l}\text { Community Psychology } \\
\text { Social Settings Analysis } \\
\text { Program Evaluation \& } \\
\text { Social Policy }\end{array}$ & Yes \\
\hline $\begin{array}{l}\text { Moncton, } \\
\text { Universite de }\end{array}$ & M.A. & $\begin{array}{l}\text { Clinique } \\
\text { Scolaire } \\
\text { Sociale }\end{array}$ & $\begin{array}{l}\text { Psychologie Sociale* } \\
\text { Psychologie Communautaire } \\
\text { Evaluation de Programme } \\
\text { d'Intervention } \\
\text { Relations de Groupes dans } \\
\text { les Organisations } \\
\text { Psychologie des Transfor- } \\
\text { mations Sociales }\end{array}$ & Oui \\
\hline $\begin{array}{l}\text { Montreal, } \\
\text { Universite de }\end{array}$ & Ph.D. & Appliquee & $\begin{array}{l}\text { Psychologie Communautaire } \\
\text { Theories de la Consultation } \\
\text { et de l'Intervention en } \\
\text { Cas de Crise } \\
\text { Evaluation et Recherche } \\
\text { dans le Domaine } \\
\text { de la Psychologie } \\
\text { Communautaire }\end{array}$ & Oui \\
\hline $\begin{array}{l}\text { New } \\
\text { Brunswick, } \\
\text { University of }\end{array}$ & M.A. & Applied & $\begin{array}{l}\text { Seminar in Social } \\
\& \text { Community Psychology } \\
\text { Community Psychology } \\
\text { Field Study }\end{array}$ & Yes \\
\hline $\begin{array}{l}\text { Ottawa, } \\
\text { Université de }\end{array}$ & Ph.D. & $\begin{array}{l}\text { Profes: } \\
\text { ionnelle }\end{array}$ & Psychologie Communautaire & Non \\
\hline $\begin{array}{l}\text { Quebec a } \\
\text { Montreal } \\
\text { Universite du }\end{array}$ & Ph.D. & Appliquee & $\begin{array}{l}\text { Psychologie et Intervention } \\
\text { Communautaire } \\
\text { Approches Behaviorales de } \\
\text { Systeme Communautaire } \\
\text { Evaluation de Programmes } \\
\text { en Intervention } \\
\text { Communautaire } \\
\text { Psychologie Communautaire } \\
\text { en Santé Mentale } \\
\text { Psychologie Communautaire } \\
\text { en Education } \\
\text { Ecologie Social }\end{array}$ & Oui \\
\hline
\end{tabular}




\begin{tabular}{|c|c|c|c|c|}
\hline University & $\begin{array}{l}\text { Highest } \\
\text { Degree } \\
\text { Offered }\end{array}$ & $\begin{array}{l}\text { Program } \\
\text { Focus }\end{array}$ & $\begin{array}{l}\text { Academic Courses in } \\
\text { Community Psychology }\end{array}$ & $\begin{array}{l}\text { Fieldwork } \\
\text { Courses in } \\
\text { Community } \\
\text { Psychology }\end{array}$ \\
\hline $\begin{array}{l}\text { Québec à } \\
\text { Trois-Rivieres, }\end{array}$ & M.A. & Clinique & Psychologie Communautaire & Non \\
\hline \multicolumn{5}{|l|}{ Université du } \\
\hline $\begin{array}{l}\text { Saint Mary's } \\
\text { University }\end{array}$ & M.A. & $\begin{array}{l}\text { Applied- } \\
\text { Clinical } \\
\text { Industrial- } \\
\text { Organiza- } \\
\text { tional }\end{array}$ & Community Psychology & Non \\
\hline $\begin{array}{l}\text { Saskat- } \\
\text { chewan, } \\
\text { University of }\end{array}$ & Ph.D. & $\begin{array}{l}\text { Clinical- } \\
\text { Community } \\
\text { Applied- } \\
\text { Social }\end{array}$ & $\begin{array}{l}\text { Community Psychology* } \\
\text { Program Evaluation } \\
\text { Organizational Psychology } \\
\text { Methods of Social Research }\end{array}$ & Yes* \\
\hline $\begin{array}{l}\text { Sherbrooke, } \\
\text { Universite de }\end{array}$ & $\begin{array}{l}\text { M.A. } \\
\text { M.A. }\end{array}$ & $\begin{array}{l}\text { Relations } \\
\text { Humaines }\end{array}$ & $\begin{array}{l}\text { Processes de Consultation } \\
\text { Intervention Communautaire } \\
\text { Changement Communautaire } \\
\text { Changement Planifié }\end{array}$ & Oui* \\
\hline $\begin{array}{l}\text { Simon Fraser } \\
\text { University }\end{array}$ & Ph.D. & $\begin{array}{l}\text { Applied- } \\
\text { Clinical }\end{array}$ & Program Evaluation & No \\
\hline $\begin{array}{l}\text { Western } \\
\text { Ontario } \\
\text { University of }\end{array}$ & Ph.D. & Applied & $\begin{array}{l}\text { Community Psychology* } \\
\text { Program Evaluation } \\
\text { Lab in } \\
\text { Community Psychology }\end{array}$ & Yes \\
\hline $\begin{array}{l}\text { Wilfrid } \\
\text { Laurier } \\
\text { University }\end{array}$ & M.A. & $\begin{array}{l}\text { Social- } \\
\text { Community }\end{array}$ & $\begin{array}{l}\text { Community Psychology* } \\
\text { Community Assessment \& } \\
\text { Program Evaluation * } \\
\text { Applied Social Psychology* } \\
\text { Field Research Methods* } \\
\text { Group Processes }\end{array}$ & Yes* \\
\hline $\begin{array}{l}\text { Windsor, } \\
\text { University of }\end{array}$ & Ph.D. & $\begin{array}{l}\text { Applied- } \\
\text { Social } \\
\text { (Community/ } \\
\text { Industrial- } \\
\text { Organiza- } \\
\text { tional) }\end{array}$ & $\begin{array}{l}\text { Community Structure } \\
\text { \& Processes } \\
\text { Community Mental Health } \\
\text { Normative Life Crises } \\
\text { Special Topics in } \\
\text { Environmental Psychology } \\
\text { Special Topics in Clinical } \\
\text { \& Community Psychology }\end{array}$ & Yes: \\
\hline $\begin{array}{l}\text { York } \\
\text { University }\end{array}$ & Ph.D. & $\begin{array}{l}\text { Clinical- } \\
\text { Counselling }\end{array}$ & $\begin{array}{l}\text { Community Psychology } \\
\text { Program Evaluation }\end{array}$ & No \\
\hline
\end{tabular}


In terms of the secondary purpose of the survey, the respondents were asked in an open-ended question to rank order up to five important areas of competence that students should learn in their community psychology training. The following is the rank ordering of the areas of competence listed by the respondents: (1) consultation, (2) program evaluation/field research, (3) planning and implementation of preventive programs, and (4) knowledge of the historical and conceptual foundations of community psychology. Given the many different models of consultation (Dworkin \& Dworkin, 1975), the consultation category includes case consultation, program/organizational development, and social action. Other areas of competence less frequently mentioned were: assessment of community needs and systems, interdisciplinary teamwork, training and supervision of nomprofessionals, interpersonal skills, etc.

Faculty were asked to evaluate the adequacy of training in their program for each of these areas of competence on a four point scale (more than adequate, adequate, less than adequate, or not available). The results of these ratings are expressed in terms of percentages of responses indicating more than adequate or adequate training for the following areas of competence: program evaluation/field research $(85 \%)$, historical/ conceptual foundations of community psychology $(70 \%)$, consultation $(50 \%)$, and planning and implementation of preventive programs $(46 \%)$. This suggests that faculty feel that they are more successful training graduate students in theory and research than in intervention strategies in community psychology.

In terms of field training experiences in these areas of competence, faculty appear to be putting into practice what they preach. The following is the rank ordering of faculty responses to an open-ended question regarding the activities of graduate students in their fieldwork courses in community psychology: (1) consultation, (2) program evaluation/field research, and (3) planning and implementation of preventive programs. On the average, students spend eight hours per week in their fieldwork activities. Furthermore, more than two-thirds of the respondents stated that students spend more than $50 \%$ of their time engaged in consultation, research, evaluation, and planning, as opposed to direct services. Students do their fieldwork in a wide variety of settings, including: mental health/public bealth agencies, non-mental health community services (e.g., corrections, mental retardation programs, voluntary groups, services for abused women, the police, etc.), programs for families and children (e.g., guidance clinics, Children's Aid Society, programs for emotionally disturbed or physically handicapped children, day care centres, etc.), and the schools.

Finally, faculty respondents in this survey identified several issues particularly relevant to graduate education in community psychology in Canada. These issues include: relations between various Canadian ethnic and cultural groups (e,g., Native and non-Native Canadians, English and French speaking Canadians), Canada's national health system and mental health policy, social service planning and evaluation for the Canadian North and geographically isolated communities, and the still pressing need to organize and develop a community psychology network in Canada.

\section{Discussion}

A major finding of this research is that opportunities for graduate education in community psychology in Canada have increased substantially in the last decade. There are now at least 20 universities (48\% of all Canadian graduate psychology programs) offering at least one graduate course in community psychology compared to only three universities 10 years ago. The fact that many of the graduate faculty who responded to this survey have moved into the area of community psychology subsequent to their own graduate education reflects the growth of community psychology 
in graduate training programs in Canada. In spite of this growth, it is important to note that graduate education in community psychology at several universities is due solely to the presence of one or two faculty.

It is very difficult to make comparisons between this Canadian survey and the previous U.S. surveys with respect to opportunuties for graduate education in community psychology because of methodological differences in the various surveys. For example, this survey considered all graduate psychology programs in Canada, while many of the U.S, surveys considered only clinical or counseling programs (e.g. Golann. Wurm, \& Magoon, 1964; Jacob, 1971: Golann, 1970). Also, the U.S. surveys used either vague or widely differing definitions of programs offering a distinguishable curriculum in community psychology. Finally, the most recent U.S. survey (Meyer \& Gerrard, 1977) with which the present survey data could be compared was done over five years ago. Thus it is not really possible to determine if Canada continues to lag behind the U.S. in terms of graduate program offerings in community psychology as it did in 1970.

In terms of program emphases and content, this survey indicates many similarities between Canadian and U.S. programs. Just as the majority of graduate programs in the U.S. offer fieldwork in community psychology (Barton, Andrulis, Grove, \& Aponte, 1976; Golann, 1970; Meyer \& Gerrard, 1977) and few offer interdisciplinary courses (Barton et al., 1976; Meyer \& Gerrard, 1977; Spielberger \& Iscoe, 1970), similar results were obtained in this survey. Community psychologists in Canada and the U.S. also appear to emphasize similar goals for graduate education in community psychology. Consultation and program evaluation/field research are the most frequently mentioned important areas of competence for community psychology training by Canadian faculty in this survey and by American faculty in previous surveys (Andrulis, Barton, \& Aponte, 1978; Barton et el., 1976). Faculty perceived the most ade- quately covered areas of training to be program evaluation/field research and the conceptual foundations of community psychology, reflecting the fact that courses in these areas are the most frequently offered. Also, the finding that skills in consultation and program planning and implementation were rated as inadequately covered or not available by approximately half of the faculty points to the need for further development and improvement in graduate education in community psychology.

Not only do respondents at Canadian and American universities agree on the goals of community psychology education, but they both stress the development of these skills in students' fieldwork. Consultation and program evaluation were the most frequently mentioned fieldwork activities both in this survey and in Jacob's (1971) U.S. survey. However, Jacob found that American students spent only $30 \%$ of their fieldwork time engaged in community psychology activities, while the majority of students in this survey spent more than $50 \%$ of their fieldwork time in community psychology activities. Again, this may be due to differences in survey methods in the two studies.

In summary, the results of this survey indicate expanded opportunities for graduate education in community psychology in Canada over the past decade. While faculty from Canadian universities agree with faculty from American universities regarding the goals of community psychology education, they expressed the need for a focus on social and professional issues relevant to Canadian community psychology (e.g., see Bennett, 1982). It is disconcerting that only two women were identified as graduate faculty in community psychology and that there is little emphasis on interdisciplinary education. To help prevent community psychology from becoming another "ology" or "ism," viz. another fad (Bender, 1976), there is a need to broaden and strengthen the base for community psychology education through the recruitment of female faculty and the support of interdisciplinary educa- 
tion. Finally, given the relative isolation of many community psychologists in Canada and the fact that community psychologists have underscored the importance of support systems in promoting growth (Gottlieb,
1979), there is a need to develop a national network to facilitate information sharing and support between community psychologists in Canada.

\section{RESUMÉ}

Un sondage national a été mené afin de déterminer quelles sont les opportunités d'une éducation graduée en psychologie communatutaire offertes actuellement au Canada. Les résultats montrent un elargissement de ce qui est offert en vie d'une éducation académique et des travaux pratiques dans le domaine de la psychologie communautaire pendant la dernière décennie. En outre. les résultats montrent les perceptions de la faculté des buts. des activités et de la suffisance de l'entrainement en psychologie communautaire. Enfin, on a noté les similarités ainsi que les différences entre l'education graduce en psychologie communautaire au Canada et aux Etats-Unis. Des questions tratitant du développement de la psychologie communautaire sont discutécs.

\section{References}

Albet. G.W. Conceptual models and manpower requirements in psychology, American Psychologist. $1968,23,317.320$.

Albee, G.W. The uncertain future of clinical psychology. American Psychologist, 1970, 25, 10711080

Albee, G.W. \& Loeffler, E. Role conflicts in psychology and their implications for a re-evaluation of training models, Canadian Psychologist, 1971. $12,465-481$

Andrulis, D, P., Burton. A.K. Aponte, J,F Perspectives on the training experiences and the training needs of community psychologists American Journal of Commanity Psycholosy: 1978, 6. $265-270$.

Arthur, A.Z. Applied training progrummes of psy. chology in Canada: A survey. Canadian Psychologist, 1971, 12, 46-65.

Babarik. P. The buried Canadian roots of community psychology, Journal of Community Prychology. $1979,7,362-367$.

Barton, A.K., Andrulis, D.P. Grove, W.P., \& Aponte. J.F. A look at community psychology training programs in the seventies American Journal of Commumity Psychology, 1976, 4, 1-11.

Bender, M.P. Community prochology. London: Methuen. 1976.

Bennett, E:M. Native persons; An assessmient of their relationship to the dominant culture and challenges for change. Canadian Journal of Community Men. tal Health, 1982, 1, 21-32.

Davidson, P.O. Graduate training and research funding for clinical psychology in Canada: Review and recommendations. Canadian Psychologist, 1970. 11. $101-127$.
Dworkin, A.L.; \& Dworkin, E.P. A conceptual overview of selected consultation mode/s. American Journal of Community Pswchology, 1975, 3. $152-160$.

Golann, S.E. Community psychology \& mental health: An amalysis of strategies and a survey of training. In I. Iscoe \& C.D. Spielberger (Eds.). Communiry psychology: Perspectives in training and research. New York: Appleton-CenturyCrofts, 1970.

Golann, S.E., Wurm, C.A., \& Magoon, T.M. Commumity mental health content of graduate programs in departments of psychology, Jinurnal of Clinical Prichology: $1964,20,518-522$

Gotulicb, B.H. The primary group as supportive milieu:-Applications to community psychology. American tournal of Community Psychology. $1979,7,469.480$.

Iscoe, I. Bloom, B.L., \& Spielberger, C.D. (Eds.). Commanity psychology in transition: Proceedings of the national conference on training in commanin psichology. New York: Wiley, 1977.

Jacob. T. A survey of graduate education in community psychology. American Psychologis7, 1971, 26. 940-944.

Meyer, M.L, \& Gerrard, M. Graduate training in community psychology. American Journal of Community Psycholosy, 1977, 5, 155-164

Spielberger, C.D. \& Iscoe, 1. Graduate education in community psychology. In S, E, Golann \& C. Eisdorfer (Eds.), Handbook of community mental healti. New York: Appleton-Century-Crofts. 1972 .

Teff, B. C, Hamilion, G.K., \& Theroux, C. Community psychology in Canada: Toward developing a national network. Canadian Journal of Commanity Mental Health, 1982, 1, 93-103 